\title{
KEBERSAMAN DALAM PEMBELAJARAN MATEMATIKA BERBANTUAN TIK
}

\author{
Oleh Edi Prayitno, \\ edip@ut.ac.id \\ UPBJJ Semarang
}

\begin{abstract}
ABSTRAK
Semangat kebersamaan merupakan salah satu karakter yang mendukung kesiapan sumber daya manusia menghadapi Masyarakan Ekonomi ASEAN. Pembelajaran matematika yang kooperatif dengan bantuan TIK mendukung peningkatan semangat kebersamaan di antara para peserta didik. Simpulan ini diperoleh dari hasil penelitian pemanfaatan TIK dalam pembelajaran matematika di SMA 4 Semarang tahun 2014. Pola pembelajaran mengalokasikan 2/3 waktu (60 menit) pembelajaran untuk kegiatan kolaboratif mandiri dalam bentuk kerja kelompok. Pembelajaran menampilkan kompetensi dasar "Penentuan volume benda putar". Guru sepenuhnya bertindak sebagai fasilitator dan mediator dalam pembelajaran. Dalam kerja kelompok para peserta didik berkolaborasi memahami uraian kompetensi dasar, memahami konsep benda putar, memahami konsep volum benda putar dan berlatih menyelesaikan soal. Interaksi selama kerja kelompok dilaksanakan menurut rambu-rambu yang telah ditentukan guru. Rambu-rambu dibuat untuk menghindari munculnya dominasi interaksi oleh satu atau beberapa peserta didik yang lebih dominan dalam kemampuan berkomunikasi atau dalam kemampuan penguasaan materi. Tiap kelompok kerja terdiri dari 3-4 peserta didik dengan kemampuan yang beragam, mulai dari yang paling menguasai materi prasyarat sampai yang paling tidak menguasai materi. Rambu-rambu antara lain menyebutkan bahwa dalam diskusi kelompok peserta didik secara bergantian mendapat giliran pertama mengutarakan pendapat atau menjawab pertanyaan; giliran untuk menanggapi pembicara pertama juga dilakukan oleh peserta didik secara bergantian sesuai rotasi yang telah ditentukan. Selain untuk menjaga kebersamaan, rambu-rambu ini juga menjamin hak dan kewajiban yang sama kepada seluruh anggota kelompok untuk mempersiapkan materi dan bertanggung jawab atas nama kelompok dalam memberi jawaban atau mengungkapkan pendapat.
\end{abstract}

Kata-Kata Kunci: Pembelajaran Kooperatif, Kerja Kelompok, Pemanfaatan TIK, Kebersamaan.

\section{PENDAHULUAN}

Sampai akhir tahun 2015 para pemimpin negara di ASEAN merencanakan pembentukan tiga komunitas bersama, yaitu komunitas ekonomi, komunitas keamanan dan politik serta komunitas sosial budaya. Tanggal 31 Desember 2015 adalah hari mulai diberlakukannya ASEAN Economy Community (AEC). Salah satu kesepakatan dalam pemberlakuan AEC adalah penghapusan tarif bea masuk hampir semua jenis barang dan terbukanya pasar tenaga kerja bersama di wilayah ASEAN (ASEAN Secretary, 2009).

Penghapusan bea masuk antara lain mengkibatkan dampak yang bertolak belakang bagi dua sisi masyarakat Indonesia, yaitu para konsumen barang dan para produsen barang. Bagi masyarakat yang mengkonsumsi produk industri, pemberlakuan AEC merupakan suatu keuntungan. Hampir semua barang dari negara-negara ASEAN bisa dipasarkan di Indonesia tanpa 
bea masuk. Di pasar Indonesia tersedia lebih banyak ragam barang berkualitas dengan harga yang lebih bersaing. Sebaliknya bagi para produsen dalam negeri, penghapusan bea masuk merupakan tantangan yang cukup berat. Produsen harus memproduksi barang yang dapat bersaing dalam kualitas dan harga dengan barang dari negara ASEAN lainnya. Industri mereka akan bangkrut bila tidak dapat bersaing. Di lain sisi masyarakat bersaing ketat dengan warga ASEAN yang lain dalam mencari lapangan kerja. Bila kualitas tenaga kerja Indonesia kalah bersaing, akan muncul angka pengangguran yang tinggi. Semakin banyak industri dalam negeri yang bangkrut dan munculnya pengangguran masif di masyarakat merupakan pertanda awal kebangkrutan ekonomi Indonesia.

Ancaman kebangkrutan ekonomi tidak dapat diatasi oleh para pelaksana negara saja. Dibutuhkan kebersamaan sikap dan tindakan dari segenap elemen bangsa, mulai rakyat sebagai konsumen, para pengusaha, sampai para pejabat negara untuk ikut menjaga tegaknya perekonomian bangsa. Masyarakat konsumen diharapkan memiliki rasa kebersamaan yang diujudkan dengan tetap mengkonsumsi produk dalam negeri. Rasa kebersamaan yang diharapkan dari masyarakat produsen adalah sikap mengutamakan penggunaan bahan baku produksi dan tenaga kerja dalam negeri. Para pejabat negara diharapkan mampu menghasilkan peraturan yang tidak membebani para pengusaha serta menciptakan lembaga pendidikan dan pelatihan yang mendorong terciptanya tenaga kerja Indonesia yang dapat bersaing dengan tenaga kerja asing.

Sikap kebersamaan sebagai salah satu karakter masyarakat tidak dapat muncul dalam sekejap. Dibutuhkan proses berkelanjutan yang meliputi semua aspek kegiatan, termasuk aspek pendidikan. Pemupukan sikap kebersamaan melalui proses pendidikan perlu dirancang secara berkesinambungan sejak usia dini sampai bangku kuliah, melalui kegiatan intra maupun ekstra kurikuler. Dalam kegiatan ekstra kurikuler para pembimbing kegiatan dituntut menciptakan suasana dan kegiatan yang mendorong tumbuh kembangnya sikap dan budaya kebersamaan. Dalam kegiatan intra kurikuler para guru perlu menemukan dan mencipta pola pembelajaran yang menumbuhkembangkan rasa kebersamaan di antara para peserta didik. Upaya menumbuhkan rasa kebersamaan di antara para peserta didik menuntut kreativitas para guru dalam menemukan model pembelajaran yang tepat, salah satunya adalah melalui model pembelajaran interaktif berbasis inkuiri berbantuan TIK.

\section{Pembelajaran Interaktif Kooperatif}

Pembelajaran kooperatif adalah pembelajaran yang memfasilitasi para peserta didik berinteraksi bersama untuk mencapai suatu tujuan tertentu (Panitz, 1999: 1; Johnson, Johnson \& Smith, 2013:3). Interaksi yang terjadi dalam proses pembelajaran adalah proses interaktivitas antara peserta didik, sistem pembelajaran dan materi pembelajaran (Hick, 1997). Sistem 
pembelajaran untuk pembelajaran 'Konsep Volum Benda Putar' menggunakan pola interaksi dengan program komputer. Interaksi yang dilakukan dalam pembelajaran adalah interaksi terbatas para anggota kelompok yang terdiri dari 3-4 orang. Selama pembelajaran inti tidak ada interaksi antar kelompok ataupun interaksi dengan guru. Interaksi yang ada hanya interaksi antar anggota kelompok dengan komputer. Guru menyusun dan menggunakan program komputer untuk menampilkan peragaan konsep, menampilkan dan menerima penyerahan tugas, menentukan serta memberikan balikan atas jawaban peserta didik. Program yang disusun diproyeksikan untuk menggantikan peran guru dalam kerja kelompok. Melalui balikan yang diberikan terhadap setiap jawaban peserta didik, program interaktif memungkinkan para peserta didik mengukur penguasaan konsep sesuai kemampuannya (Kirk, 2015). Program tersebut memungkinkan peserta didik untuk menghentikan sementara atau mengulang tampilan tayangan materi bila dibutuhkan.

Penggunaan multimedia yang interaktif dalam pembelajaran memunculkan suasana belajar yang lebih menyenangkan (Hick, 1997). Melalui tampilan video, para peserta didik diajak berpikir imajinatif dan logis menganalisis animasi untuk menarasikan konsep, melalui interaksi penyelesaian masalah para peserta didik ditantang untuk berkolaborasi berpikir kritis menemukan penyelesaian masalah. Kerjasama penyelesaian masalah dilakukan melalui debat dan diskusi dengan teman satu kelompok. Kerjasama ini dapat memberikan hasil belajar yang maksimal. Kegiatan debat dan diskusi dengan teman sejawat membuat para peserta didik menjadi lebih emosional terlibat dalam kegiatan belajar (Anderson, 2014).

Multimedia yang menampilkan simulasi video atau animasi sederhana memungkinkan peserta didik belajar dengan melihat, belajar dengan melakukan dan belajar melalui pembinaan. Ketiga pola belajar ini merupakan pola belajar yang efektif untuk mengembangkan keterampilan praktis dan meningkatkan retensi informasi (Hick, 1997). Selain dilatih berpikir imajinatif, logis dan kritis, para peserta didik didorong aktif selama pembelajaran (Revermann, 2015). Keaktifan peserta didik dikondisikan melalui pengaturan bergantian bertindak sebagai nara sumber utama di dalam masing-masing kelompok kerja, baik saat mengungkap konsep maupun saat menyelesaikan masalah. Pengetahuan tentang volum benda putar diperoleh melalui mengkonstruk, menemukan dan mentransformasikan ke dalam pikiran. Guru mengkondisikan lingkungan belajar sehingga para peserta didik dapat menyusun konsep dengan cara memprosesnya melalui struktur kognitif yang ada dan menyimpannya dalam ingatan jangka lama (Johnson \& Smith dalam Panitz, 1999:3).

Program interaktif dikemas dalam sebuah compact disc (CD). Di luar waktu pembelajaran, program interaktif dapat diputar ulang tanpa batasan waktu dan tempat selama ada perangkat komputer atau laptop. Tingkat kemajuan penguasaan materi suatu kelompok kerja tidak dipengaruhi oleh kelompok lain. Para peserta didik dapat bekerja sama dan saling bertukar 
informasi tanpa harus berkumpul melalui interaktif online (Kirk, 2015). Penguasaan materi dapat diperdalam dan diperkaya di luar proses pembelajaran di kelas.

\section{Kebersamaan Kelompok Kerja}

Pembelajaran kooperatif didasarkan pada kebutuhan peserta didik sebagai makhluk sosial untuk berinteraksi dengan sesama. Namun selain sebagai makhluk sosial, peserta didik dikodratkan juga sebagai makhluk yang otonom (berkehendak). Sosialitas dalam kebersamaan komunal, termasuk di dalamnya kebersamaan dalam kerja kelompok, dilakukan dalam rangka saling melengkapi. Kamus Besar Bahasa Indonesia mengartikan kata 'kebersamaan' sebagai 'hal bersama' (Alwi, 2005: 986). Dalam Bahasa Inggris 'togetherness' (kebersamaan) diartikan sebagai 'a feeling of closeness or affection from being united with other people' (Collins, 2012). Kebersamaan adalah suatu keinginan untuk bersatu dengan orang lain. Kebersamaan melibatkan proses interaksi antara dua orang atau lebih.

Interaksi dalam kebersamaan kerja dipicu oleh adanya kesamaan misi, yaitu menyelesaikan tugas kerja. Kebersamaan dapat ditingkatkan melalui penumbuhan rasa aman, rasa saling memiliki, kerja sama dan perasaan saling mendukung (Charles, 2008) yang diperoleh melalui proses interaksi dan komunikasi. Komunikasi yang hangat dan cair selama kerja kelompok dengan tujuan yang sama akan memunculkan rasa saling memiliki dan saling mendukung. Melalui proses interaksi yang intensif kadar kebersamaan semakin meningkat dan memunculkan kesamaan visi antar anggota.

Teori umum perilaku manusia menyebutkan bahwa ada dua alasan seseorang berinteraksi, yaitu: memperoleh teman untuk bekerja bersama dan mendapatkan orang lain bekerja untuk kita (Wrona, 2009). Dalam upaya untuk memperoleh teman dan untuk memperoleh bantuan dari teman terselip tendensi egoisme individu. Egoisme individu akan tetap terjaga karena adanya etika yang lahir dalam kebersamaan. Etika muncul dalam suatu kebersamaan komunal. Kebersamaan komunal lahir hanya bila sekelompok individu dimiliki pemahaman yang sama. Etika melarang anggota menisbikan anggota lain. Seseorang tidak dapat dan seharusnya tidak mengatur orang lain. Setiap individu harus memberi kesempatan kepada orang lain untuk menampilkan kemauannya sendiri (Wu, 1998). Etika yang mengayomi egoisme individu ini bisa membahayakan pencapaian tujuan sebagai salah satu aspek yang menjadi perhatian utama dari kebersamaan dalam kelompok kerja.

Tidak bisa diabaikan bahwa aspek rasa dan karsa tiap individu sering kali menimbulkan perbedaan kepentingan. Untuk memfasilitasi perbedaan kepentingan dan menjamin tercapainya tujuan kebersamaan, di satu sisi diperlukan kiat untuk mengakomodasi perbedaan sikap dan 
pendapat tiap individu serta di sisi lain dituntut sikap individu yang dapat menahan diri. Otonomi dalam sosialitas menuntun kebersamaan untuk mewujudkan demokrasi setempat. Manusia memerlukan manajemen sosial untuk bertahan hidup, namun otoritas bersama sebagai perwakilan kehendak para individu diperlukan untuk menegakkan koordinasi kerja (Wu, 1998). Koordinasi kerja dibutuhkan sebagai pembatas untuk mencegah kepentingan pribadi yang melampaui batas.

Koordinasi kerja memegang peranan penting untuk tetap menjaga kebersamaan karena selama proses interaksi akan terjadi salah satu dari lima kemungkinan berikut, yaitu: 1) meminta bantuan seseorang 2) mengubah tujuan seperti yang diinginkan, 3) bersama teman mengubah tujuan sehingga menjadi lebih diterima dan berusaha bersama, 4) meninggalkan kebersamaan atau menghentikan interaksi, 5) memusuhi atau berargumen (Wrona, 2009). Koordinasi kerja diperlukan untuk menghindari kemungkinan pecahnya kebersamaan karena adanya anggota yang menghentikan interaksi, munculnya permusuhan atau adu argumentasi yang meruncing.

Koordinasi kerja yang baik akan memunculkan sikap saling menerima. Sikap saling menerima akan melanggengkan kebersamaan karena sikap saling menerima akan memunculkan kesediaan mengakomodasi dan mengakui seseorang sebagai manusia seutuhnya, menisbikan diri sendiri untuk memberi kesempatan orang lain mengaktualisasikan diri, dan pada saatnya nanti akan memunculkan pengakuan orang lain pada diri kita sendiri (Wu, 1998). Keinginan bersatu menunjukkan adanya kerelaan dan kesediaan untuk saling memahami, saling mendengar, saling berbagi dan saling peduli. Kepedulian akan memunculkan kerelaan untuk saling menolong.

Namun dalam perjalanannya koordinasi kerja yang didasarkan pada kesamaan misi dan visi tidak menjamin kelanggengan kebersamaan. Manusia dikarunia ragam sikap dan pandangan yang sangat bervariasi. Rasa kebersamaan memperkuat efek kepemilikan psikologis berbasis pekerjaan. Efek psikologis ini memicu penampilan perilaku keterlibatan aktif (Andiyasari, 2013). Keinginan keterlibatan aktif sebenarnya bernilai positip, namun bila keinginan tersebut dilaksanakan secara dominan di dalam suatu kerja kelompok akan menimbulkan dampak yang negatip, yaitu munculnya superioritas di antara anggota kelompok. Peran mediator diperlukan untuk mengatur pola keterlibatan aktif para anggota.

Penelitian yang dilakukan di SMA 4 Semarang pada tahun 2014 selain ditujukan untuk mengoptimalkan penguasaan kompetensi dasar 'Menentukan volum benda putar', juga dimaksudkan untuk mengembangkan rasa kebersamaan di antara para peserta didik. Pembelajaran ditampilkan melalui model pembelajaran interaktif berbasis inkuiri berbantuan TIK. Sesuai dengan karakteristik pembelajaran inkuiri, pembelajaran menempatkan keingintahuan, gagasan dan kegiatan pengamatan peserta didik sebagai pusat pengalaman belajar (SAD, 2013). Guru berusaha menanamkan budaya untuk senang menantang, menguji, mendefinisikan ulang dan 
mengembangkan suatu gagasan. Para peserta didik bekerja dalam kelompok kecil mengeksplorasi gagasan dan keingintahuan mereka dalam kegiatan mengamati materi CD interaktif.

Dengan bantuan CD interaktif guru berusaha membantu para peserta didik untuk mengubah pemahaman intuitif dan rasa ingin tahu menjadi penciptaan ilmu, yaitu mengubah gagasan yang ditampilkan menjadi pemahaman yang diformalkan dan mendorong munculnya pertanyaan lebih lanjut. Langkah-langkah yang telah diprogram dalam CD interaktif dapat mengarahkan peserta didik mengembangkan keterampilan dan kemampuan secara lebih mandiri. Melalui langkahlangkah pembelajaran yang diprogram dalam CD interaktif, guru menampilkan model untuk mengembangkan cara mengemukakan dan mengembangkan gagasan, cara bertanya dan cara melaksanakan investigasi terhadap konsep volume benda putar.

Para peserta didik dikelompokkan dalam beberapa kelompok kecil yang beranggota 3 atau 4 orang. Setiap kelompok dibebani tugas kolektif memahami konsep, menguji pemahaman konsep, mendefinisikan ulang konsep dan mengembangkan konsep volume benda putar. Tanggung jawab kognitif secara kolektif merupakan salah satu komponen penting dalam menjalin kebersamaan antar anggota. Tanggung jawab kolektif dalam prosesnya menampilkan aspek pembelajaran yang berlanjut, fleksibilitas, pola berpikir yang rasional dan kerjasama (Scardamalia, 2002).

Melalui CD interaktif guru memfasilitasi para peserta didik secara aktif mengekplorasi materi 'volum benda putar' secara mandiri dalam kerja kelompok. Proses belajar berubah menjadi kegiatan diskusi kelompok mandiri. Dalam kebersamaan peserta didik secara leluasa dapat mengajukan pertanyaan kepada teman satu kelompok dan akan segera memperoleh tanggapan. Guru sepenuhnya berfungsi sebagai seorang fasilitator dalam proses penguasaan konsep. Pola interaksi dua arah antara guru dan peserta didik diganti dengan interaksi kelompok kerja dan komputer. Dalam interaksi antara guru dan peserta didik, inisiasi kegiatan dan urutan langkah pembelajaran ditentukan oleh guru, sedangkan dalam interaksi kelompok kerja dan komputer, inisiasi sebagian besar ditentukan oleh kelompok kerja, hanya di bagian latihan dan kuis inisiasi ditentukan oleh program komputer.

Pada awal pembelajaran setelah menyimak paparan tujuan pembelajaran, kebersamaan peserta didik terlihat saat pembentukan kelompok kerja. Tidak ada satupun peserta didik yang menolak keanggotaan peserta didik yang lain di dalam kelompok kerja. Sikap penerimaan terhadap siapapun teman satu kelompok kerja mencerminkan sikap kebersamaan. Kebersamaan dalam kerja kelompok dilakukan selama 50 menit kegiatan inti pembelajaran. Para peserta didik diberi tanggung jawab kolektif dalam: 1) memaknai kompetensi dasar, 2) memahami dan mendefinisikan ulang konsep benda putar, 3) mengembangkan konsep benda putar melalui konsep volum dan 4) mengembangkan konsep volum melalui penyelesaian soal. 


\section{Berbagi Pemahaman melalui Interaksi Kelompok}

Pada kegiatan sesi kedua dan ketiga, kelompok kerja menikmati tayangan video animasi tentang konsep benda putar dan konsep volum benda putar. Pemahaman tentang kedua konsep diperoleh dari hasil interaksi kelompok. Guru sengaja tidak memaparkan

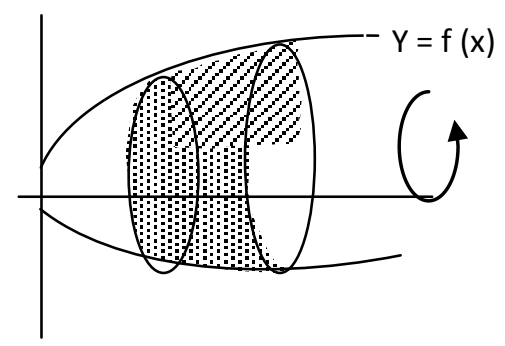

Gambar. 1 Perputaran benda pada sumbu X

(Prayitno, 2015:5)

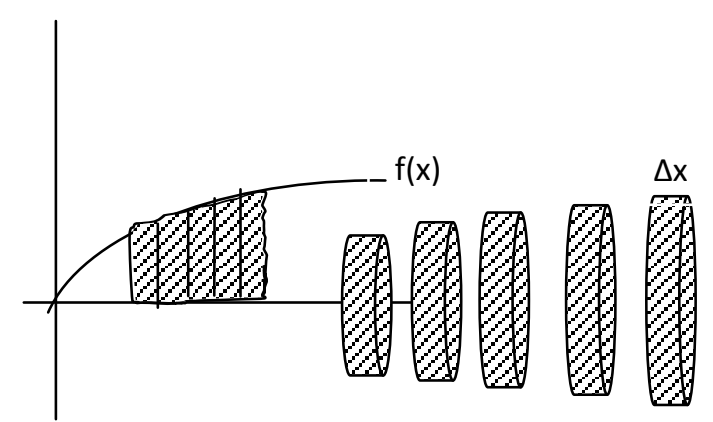

Gambar. 2 Irisan benda dalam Konsep volum benda putar

(Prayitno, 2015:5)

konsep benda putar secara eksplisit dalam tayangan animasi. Ia berharap para peserta didik berbagi pemahaman melalui interaksi sosial dalam kelompok kerja untuk menemukan konsep tersebut secara mandiri. Interaksi antar peserta didik diyakini memberikan makna yang lebih dalam segala hal bila dibanding dengan interaksi antara peserta didik dengan guru. Interaksi antar peserta didik memberikan kedekatan emosi yang lebih dalam. Mereka lebih saling memahami bahasa lisan, bahasa tubuh dan kebiasaan masing-masing (Tsai, 1998). Komunikasi berikut ini mencerminkan adanya saling pemahaman bahasa lisan, bahasa tubuh dan kebiasaan antar anggota.

Jihan: "Tak kiro benda putar kuwi benda yang bisa berputar, ee..nyatane salah"

Fitri : "Sing bener benda putar iku opo?"

Jihan: "Iku sing kebentuk dari perputaran kurva di suatu poros, bener kan?"

Fitri : "He...hee... pinter." 
Di setiap kelompok muncul salah satu peserta didik yang memulai berbagi pemahaman yang membuka proses interaksi. Tanpa diminta oleh teman yang lain, Aldi yang satu kelompok Cininta, Lintang dan Dhea menggantikan giliran Lintang yang seharusnya menjadi nara sumber untuk sesi tersebut. Setelah menunggu namun tidak kunjung ada penjelasan dari Lintang, Aldi menerjemahkan tampilan animasi tentang konsep volum benda putar.

Aldi :" Benda putar bila diiris dengan satuan tinggi delta x akan berbentuk silinder. Di tayangan, benda putarnya diiris menjadi lima silinder dengan satuan tinggi $\Delta x$. Volum benda putar sama dengan jumlah volum kelima silinder."

Dhea:” Kalau bendanya diiris menjadi delapan silinder, maka volum benda putar sama dengan jumlah volume ke delapan silinder, benar kan?”

Aldi:“ Benar. Dhea, ingat kan rumus volume silinder? “"

Dhea:" Ya, luas alas kali tinggi. Alasnya berbentuk lingkaran dan tingginya $\Delta x$ sehingga tiaptiap silinder volumnya $=\pi r^{2} \Delta x . "$

Aldi:" Bila volum tiap silinder ditemukan, maka volum benda putar adalah jumlah semua volum silinder yang ada."

Sesuai dengan Teori Kognitif Sosial, kesediaan individu berbagi pemahaman tidak lepas dari pengaruh jaringan sosial yang ada di sekelilingnya (Bandura, 2001:2). Kemunculan kesediaan berbagi pemahaman tidak lepas dari adanya kedekatan emosi antar individu. Kedekatan emosi mendorong individu untuk memiliki rasa dan karsa dalam berkontribusi begi kelompok. Rasa dan karsa pribadi menciptakan kesadaran individu untuk berbagi dalam komunitas. Kesadaran berbagi pemahaman dalam komunitas tidak hanya didorong adanya manfaat bagi pribadi, namun juga didorong adanya manfaat bagi kelompok (Chiu, 2006; 1873). Kesadaran adalah inti pikiran yang membuat hidup seseorang menjadi terencana dan bermanfaat (Bandura, 2001; 3). Kesadaran menjadi pondasi untuk berpikir.

Kesadaran berbagi dapat menjadi benih tumbuhnya kepercayaan dalam kelompok kerja. Kepercayaan telah dipandang sebagai aspek utama kebersamaan. Kepercayaan menjadi suatu harapan untuk meredakan ketakutan bahwa seseorang akan bertindak oportunis (Tsai, 1998). Ketika semua anggota kelompok kerja sudah saling percaya, mereka menjadi lebih bersedia untuk berbagi pemahaman. Kepercayaan dan keakraban yang telah terbangun di antara para anggota kelompok kerja dapat menghapus kekhawatiran bahwa salah satu peserta akan mengambil keuntungan pribadi. Perilaku kooperatif lainnya segera menyusul muncul setelah ada kepercayaan. 


\section{Koordinasi Kerja dalam Kerja Kelompok}

Kerja kelompok, apapun tujuannya dan berapapun anggotanya dipastikan sudah memiliki komunikasi awal sebagai koordinasi pelaksanaan. Koordinasi pelaksanaan diperlukan untuk memastikan tujuan yang akan dicapai, kegiatan yang akan dilakukan untuk mencapai tujuan dan keputusan tentang kegiatan yang akan dilakukan (McNamara, 2015). Namun dalam kerja kelompok saat pembelajaran, untuk menghemat waktu pembelajaran, koordinasi pelaksanaan dapat digantikan oleh petunjuk kerja. Dalam pembelajaran konsep volum benda putar, sejak awal pembelajaran guru telah menyusun petunjuk kerja kelompok. Petunjuk kerja tersebut merupakan upaya antisipasi guru terhadap kemungkinan adanya kekacauan proses komunikasi dalam penyelesaian tugas. Petunjuk kerja menjadi formalisasi kebijakan, taktik, aturan dan deskripsi kerja yang menjelaskan secara eksplisit arah operasional yang harus diambil (Isac, Voichita \& Guta, 2009:339). Petunjuk kerja menjadi acuan koordinasi kerja dalam kelompok untuk mencegah terjadinya kekacauan dan kebingungan (Chand, 2015).

Sebagai manajer pembelajaran, guru memiliki kewajiban untuk mengkoordinasi kegiatan pembelajaran, yaitu mengatur keterkaitan unit-unit yang terpisah (Karmakar \& Datta. 2012: 248) dalam proses pembelajaran. Tiap-tiap unit pembelajaran dirangkai secara harmonis membentuk satu unit (Chand, 2015) pembelajaran yang efektif. Dalam kerja kelompok, koordinasi yang dilakukan guru dimaksudkan untuk menggerakkan seluruh peserta didik untuk aktif, menyerasikan jenis kegiatan, menyelaraskan giliran dan menyeimbangkan peran masing-masing anggota dalam kerja kelompok. Kewenangan tersebut dituangkan dalam lembar koordinasi kerja kelompok. Koordinasi ini dilakukan untuk mengintegrasikan kegiatan (Akrani, 2011), mengefektifkan pembagian kerja (Ndraha, 2003: 290) dalam kelompok meskipun beranggota sedikit (Karmakar \& Datta. 2012: 250), antara 3-4 orang. Tanpa koordinasi gerak langkah para anggota kelompok tidak dapat disatukan dan dintegrasikan (Chand, 2015) untuk mencapai tujuan kelompok.

Dari pengalaman pembelajaran dengan metode belajar kelompok, guru dapat mengidentifikasi beberapa kelemahan pelaksanaan kerja kelompok oleh peserta didik sekolah dasar, salah satunya adalah terdapatnya beberapa peserta didik yang pasif dalam kelompok. Sikap pasif mereka tidak selamanya dikarenakan kemalasan mereka. Sikap pasif peserta didik dalam suatu kerja kelompok bisa disebabkan buruknya interaksi dalam kelompok kerja.

Pembelajaran inkuiri interaktif dengan bantuan compact disc (CD) melalui tugas kelompok menuntut interaksi yang baik dalam mencapai tujuan. Interaksi yang muncul diharapkan mampu secara merata memberikan kesempatan semua anggota kelompok berperan serta. Pembelajaran terbagi ke dalam empat bagian, masing-masing dengan tujuan/tuntutan yang berbeda. Bagian pertama tiap kelompok dituntut mampu mengungkap kembali tuntutan kompetensi darat, bagian kedua dituntut mendefinisikan ulang konsep bangun putar, bagian ketiga dituntut mengungkap 
rumus volum bangun ruang dan bagian keempat dituntut menyelesaikan masalah tentang menentukan volum ruang.

Melalui petunjuk kerja guru ingin mengordinasikan supaya anggota secara bergiliran para anggota kelompok mengungkapkan hasil pemikiran pertama kali pada suatu bagian atau soal, pemikiran tersebut selanjutnya ditanggapi dan disempurnakan oleh anggota lain. Bila terjadi kebuntuan pemikiran atau terjadi pertentangan pendapat yang tajam, diharapkan muncul seorang mediator diantara anggota kelompok kerja atau mencatat permasalahannya untuk dikonsultasikan ke guru di lain waktu.

\section{Mediator Kebersamaan}

Di dalam petunjuk kerja disebutkan bahwa bilamana ada dua anggota berbeda pendapat, maka anggota yang ketiga atau keempat bertindak sebagai mediator yang rasional dan bijak. Mediator dalam memberikan mediasi diharuskan tidak memihak dan dapat diterima kedua belah pihak (Soemartono, 2006:120; NYPI, 2011; ACAS, 2015). Mediasi adalah percakapan antara dua orang atau dua pihak yang berbeda pendapat (NYPI, 2011). Mediator dapat berkomunikasi dengan kedua belah pihak secara terpisah maupun bersama-sama. Dalam memberikan mediasi, mediator tidak diperbolehkan memberikan kesimpulan atau memberikan jawaban penyelesaian (Soemartono, 2006:122; NYPI, 2011; ACAS, 2015).

Mediator perlu membangun kepercayaan para pihak yang berbeda pendapat. Pada awal langkah mediasi, mediator harus melakukan penelurusan kesamaan dengan kedua pihak yang berbeda pendapat (Soemartono, 2006:120). Setelah diperoleh kesamaan pendapat, mediator mengajukan pertanyaan-pertanyaan yang dapat membantu mengungkap akar perbedaan, membantu kedua pihak untuk memperjelas pilihan menyelesaikan perbedaan (ACAS, 2015) atau membantu kedua belah pihak menyatukan pendapat mereka sendiri (NYPI. 2011).

Tujuan utama mediasi adalah mendiskusikan perbedaan (Soemartono, 2006: 120) serta menyatukan pendapat untuk mendapatkan jawaban yang tepat atas soal yang ditampilkan dalam $\mathrm{CD}$, bukan untuk menentukan pendapat siapa yang salah maupun yang benar. Selama proses mediasi, kedua pihak yang berbeda pendapat sepenuhnya difasilitasi mengungkapkan pendapat mereka dalam suasana kekeluargaan (NYPI, 2011).

Selama pembelajaran konsep volum benda putar fungsi mediator dalam masing-masing kelompok kerja tidak nampak. Setiap konsep dan permasalahan dapat diselesaikan dengan baik melalui komunikasi yang penuh kekeluargaan. Tidak ada perbedaan pendapat yang sampai membutuhkan munculnya mediator. Kebersamaan para anggota kelompok kerja senantiasa terjaga dalam dinamika kerja yang tinggi disertai komunikasi yang hangat selama proses pembelajaran. 


\section{PENUTUP}

Kebersamaan seluruh warga Indonesia diperlukan untuk menjaga tetap tegaknya ekonomi bangsa dalam menyongsong diberlakukannya Masyarakat Ekonomi Asean. Sebagai komponen bangsa yang berkiprah di dunia pendidikan, kita dituntut menumbuhkan dan mengembangkan sikap kebersamaan di antara para peserta didik, para guru dan para pelaksana lembaga pendidikan. Penumbuhan dan pengembangan sikap kebersamaan dilakukan pada setiap kesempatan interaksi yang ada, baik dalam interaksi di luar kelas, di dalam kelas maupun di luar lingkungan sekolah.

Guru memegang kendali yang sangat signifikan dalam penumbuhan dan pengembangan kebersamaan di dalam kelas. Sebagian besar waktu berinteraksi di dalam kelas dilakukan melalui kegiatan pembelajaran. Dalam merancang kegiatan pembelajaran inilah peran guru sangat dominan untuk dapat menumbuhkembangkan sikap kebersamaan para peserta didik. Terdapat beragam model pembelajaran yang dapat menumbuhkan sikap kebersamaan, tinggal kesadaran, kemauan dan kesungguhan kita untuk mewujudkannya. 


\section{DAFTAR PUSTAKA}

ACAS. 2015. Mediation. Acas: Help \& advice for employers and employees. http://www.acas.org. uk/index.aspx?articleid $=4522$

Akrani, Gauray. 2011. What is Coordination? Meaning and Articles on Co-ordination. Kalyan City Life.

Alwi, Hasan. 2005. Kamus Besar Bahasa Indonesia. Cetakan Keempat Edisi III. Jakarta: Balai Pustaka.

Anderson, Jill. 2014. The Benefit of Interactive Learning. Harvard Graduate School of Education. http:// www.gse.harvard.edu/news/14/11/benefit-interactive-learning

Andiyasari, Andin. 2013. Peranan Faktor Kontekstual dan iidividual dalam Hubungan antara Kepemilikan Psikologis dan Inisiatif Perubahan. Disertasi. Universitas Indonesia. Diunduh dari http://lib.ui.ac.id/opac/themes/libri2/detail.jsp?id=20329052\&lokasi=lokal pada Juli 2015.

ASEAN Secretary. 2009. Roadmap for an ASEAN Community 2009-2015. Jakarta: ASEAN Secretariat. Diunduh dari http://www.smecorp.gov.my/vn2/sites/default/files/RoadmapASEANCommunity-2.pdf pada Juli 2015.

Bandura, Albert. 2001. Social Cognitive Theory: An Agentic Perspective. Annual Reviewsof Psychologist. 2001.52: 1-26. Diunduh dari http://moodle2.cs.huji.ac.il/nu14/pluginfile.php/179670/mod_ resource/content/1/Bandura_2001.pdf. Pada 7 Agustus 20015.

Chand, Smriti. 2015. 6 Features of Coordination in Management; Business Management. Your Article Libraty.com. http://www.yourarticlelibrary.com/management/6-features-ofcoordination-in-management-business-management/8618/

Charles, C.M. 2008. Paths to Positive Discipline. Diunduh dari http://www.learningace.com/doc/ 7712627/00df84b28d4e160e0f7579b48f41af96/strategy pada Agustus 2015.

Chiu, Chao-Min; Hsu, Meng-Hsiang; Wang, Eric T.G. 2006. Understanding knowledge sharing in virtual communities: An integration of social capital and social cognitive theories. Science Direct, Decision Support Systems 42 (2006) 1872-1888. Diunduh dari http:// www.researchgate.net/profile/Eric_Wang25/publication/222422090_Understanding_knowl edge_sharing_in_virtual_communities_An_integration_of_social_capital_and_ social_cognitive theories/links/549ab2060cf2b8037136f46d.pdf pada 2 Agustus 2015.

Collins , William. 2012. Collins English Dictionary - Complete \& Unabridged 2012 Digital Edition. Diunduh dari http://dictionary.reference.com/browse/togetherness pada Juli 2015.

Hick, Steven. 1997, Benefits of Interacktive Multimedia Courseware. Carleton University. http://http-server.carleton.ca/ shick/mypage/benifit.html 
Isac, Claudia; Voichita, Luminita \& Guta, Anca Jarmila. 2009. Coordination of Management Activities - A Condition Sine Qua Non of a Performance Management. Journal. Annals of the University of Petrocani, Economics, 9(3), 2009, 335-340.

http://upet.ro/annals/economics/pdf/2009/20090339.pdf

Johnson, David W.; Johnson, Roger T. and Smith, Karl. 2013. Cooperative Learning: Improving University Instruction By Basing Practice on Validated Theory. University of Minnesota. http://personal.cege.umn.edu/ smith/docs/Johnson-Johnson-Smith-Cooperative_LearningJECT-Small_Group_Learning-draft.pdf

Karmakar, Anupam \& Datta, Bidisha. 2012. Principles and Practice of Management and Business Communication. India: Dorling Kindersley Pvt, Ltd. https://books.google.co.id/ books?id= xqXiWDePQeQC\&pg=PA249\&lpg=PA249\&dq=coordination, + g+r+terry \&source=bl\&ots=ECRzH-e0Xw\&sig=jc7FcCKAg0_7PbIpOs 1csF6rZq8\&hl=id\&sa= $\underline{X} \&$ rediresc $=\mathrm{y} \# \mathrm{v}=$ onepage $\& \mathrm{q}=$ coordination $\% 2 \mathrm{C} \% 20 \mathrm{~g} \% 20 \mathrm{r} \% 20$ terry $\& \mathrm{f}=$ false

Kirk, Alan. 2015. What are the Benefits of Interactive Learning? http://www.ehow.com/list 6468331_benefits-interactive-learning_html

McNamara, Carter. 2015. Management Function of Coordinating/Controlling: Overview of Basic Methods. Article in Free Management Library. http://managementhelp.org/ managementcontrol/

Ndraha, Taliziduhu. 2003. Kybernology (Ilmu Pemerinahan Baru) 2. Rineka Cipta.

NYPI. 2011. Facts about Mediation. New York Peace Institute. http://nypeace.org/mediationservices/

Panitz, Theodore. 1999. Collaborative Versus Cooperative Learning; A Comparison of the Two Concepts which Will Help us Understand the Underlying Nature of Interactive Learning. Educational Resources Information Center (ERIC). http://files.eric.ed.gov/fulltext/ ED448443.pdf

Prayitno, Edi. 2015. Mathematical Communication in Interactive Learning. Makalah dalam International Conference on Educational Research and Innovation. Yogyakarta: UNY.

Revermann, Susan. 2015. Interactive Learning Definition. http://www.ehow.com/about 5494900_interactive-learning-definition.html.

SAD (Student Achievement Division), 2013. Inquiry-based Learning. Artikel pada Capacity Building Series. DIunduh dari https://www.edu.gov.on.ca/eng/literacynumeracy/inspire/research/CBS InquiryBased.pdf.

Scardamalia, Marlene. 2002. Collective Cognitive Responsibility for the Advancement of knowledge. Diunduh dari http://citeseerx.ist.psu.edu/viewdoc/download?doi $=10.1 \cdot 1.197 .7385 \& \mathrm{rep}=\mathrm{rep} 1$ \&type=pdf

Soemartono, Gatot. 2006. Arbitrase dan Mediasi di Indonesia. Jakarta: PT Gramedia Pustaka Utama. 
Tsai, Wenpin dan Goshal, Sumantra. 1998. Sosial Capital and Value Creation: The Role of intrafirm Networks. The academy of management Journal, Vol. 41 No $4 . \quad$ Stable URL:http://links. jstor.org/sici? sici=00014273\%28199808\%2941\%3A4\%3C464\%3ASCAVCT\%3E2.0.CO\%3B2-1

Wrona, Dave. 2009. Human Behavior Model: General Theory of Human Behavior. May 18, 2009. Diundah dari http://www.slideshare.net/davewrona/human-behavior-model-general-theoryof-human-behavior

Wu, Kuang Ming. 1998. On The logic of Togetherness: A Cultural hermeneutic. Brill. Amazone.com. Diunduh dari https://books.google.co.id/books/about/On_the_Logic_of Togetherness.html?i d=eqqIM7I_GwEC\&redir_esc=y. 